\title{
13
}

\section{Chloroplast DNA from 16th century waterlogged oak in a marine environment: initial steps in sourcing the Mary Rose timbers}

\author{
Alanna K. Speirs ${ }^{1}$, Glenn McConnachie ${ }^{2}$ and Andrew J. Lowe ${ }^{3,4}$ \\ 1. School of Social Science \\ The University of Queensland \\ Brisbane QLD 4072 Australia \\ Email: alanna.speirs@gmail.com \\ 2. Conservation Manager, Mary Rose Trust \\ College Road, HM Naval Base \\ Portsmouth PO1 3LX United Kingdom \\ 3. The School of Integrative Biology \\ The University of Queensland \\ Brisbane QLD 4072 Australia \\ 4. School of Earth and Environmental Science \\ University of Adelaide \\ Adelaide SA 5000 Australia
}

\begin{abstract}
This paper reports initial results of a palaeogenetic analysis of timbers from the hull of the English Tudor flagship Mary Rose. The study is the first step in assessing the feasibility of extracting and amplifying chloroplast DNA (cpDNA) from these timbers, which were preserved in a marine environment for more than four centuries. The ultimate goal of this research is to determine the provenance of oak (Quercus spp.) used in the ship's manufacture, following previous work demonstrating that the chloroplast genome of modern European oak populations exhibits a strong phylogeographic structure. Experimental trials revealed that extraction methods developed for modern oak wood were inadequate owing to the presence of polymerase chain reaction (PCR) inhibitors in the Mary Rose timbers. A series of treatments were tested to develop a new extraction protocol, resulting in cpDNA recovery from one archaeological sample. These results represent the first successful extraction and amplification of cpDNA from waterlogged archaeological oak wood from a marine environment.
\end{abstract}

\section{KEYWORDS}

oak wood, DNA, palaeogenetics, PCR, chloroplast, Mary Rose

\section{INTRODUCTION}

This paper reports initial results of a palaeogenetic analysis of timbers from the hull of the English Tudor flagship Mary Rose. The study is the first step towards an ultimate goal of determining the geographic provenance of oak (Quercus spp.) used in the ship's manufacture. Stage I of the research program was designed to test the viability of extracting and amplifying DNA from the 
waterlogged Mary Rose timbers, which were submerged in a marine environment for more than four centuries.

\section{PALAEOGENETICS AND OAK}

Palaeogenetics, the study of ancient DNA (aDNA), offers direct genetic evidence of extinct and extant species from preserved samples (Capelli et al. 2003; Gugerli et al. 2005; Hofreiter et al. 2001; Pääbo et al. 2004). After the death of an organism, hydrolytic and oxidative processes cause fragmentation and modification of DNA (Lindahl 1993; Pääbo et al. 2004). These processes reduce the size of DNA fragments that may be successfully amplified using the polymerase chain reaction (PCR), resulting in average aDNA fragment lengths of 50-500bp (Hofreiter et al. 2001; Hoss et al. 1996; Pääbo 1989; Pääbo et al. 2004). However, using PCR primers designed to target small fragments, aDNA up to tens of thousands of years old has been successfully amplified from the tissues of animals and plants (Pääbo et al. 2004).

Wood is one of the most common archaeological plant remains (Gugerli et al. 2005), and the application of palaeogenetics to wooden archaeological artefacts may reveal a wealth of information about the genetic structure of past natural populations. Such information has potential applications in studies of wood traceability, historical shipbuilding, resource management and trade. Other potential applications include modern forest management, species conservation and monitoring climate change and evolution of species (Capelli et al. 2003; Deguilloux et al. 2002; Dumolin-Lapegue et al. 1999; Gugerli et al. 2005; Tani et al. 2003).

European oaks of the genus Quercus provide a suitable case study for genetic determination of provenance as oak cpDNA remains unaltered through many generations (Ferris et al. 1993). Present oak populations are likely therefore to reflect variation that has been established for hundreds of years (Hewitt 1999; Petit et al. 1993). Analysis of cpDNA from fresh bud and leaf samples from 2613 Quercus populations Europe-wide identified polymorphisms that distinguish 32 distinct genotypes, referred to as haplotypes (Dumolin-Lapegue et al. 1997; Ferris et al. 1993, 1995; Petit et al. 1993; Petit et al. 2002). Maps constructed from these data demonstrate patchy haplotype distributions that tend to run along a longitudinal gradient and are differentiated by latitude (Hewitt 1999; Petit et al. 2002). Chloroplast DNA haplotype maps corroborate patterns of oak post-glacial colonisation deduced from palynological studies that identify Iberia, Italy and the Balkans as regions of refugia during the last glacial period ( 115ka - 15kyr BP). Therefore, oak cpDNA variation exhibits a strong phylogeographic structure that reflects patterns of oak post-glacial migration northwards during the Holocene (10kyr BP - present) (Brewer et al. 2002; Huntley and Birks 1983; Petit et al. 2002).

Although all early oak haplotype work used fresh leaf and bud tissues as a DNA source, recent studies have demonstrated that is possible to extract and amplify chloroplast DNA from oak wood. Between 2002 and 2004, Deguilloux and colleagues developed molecular tools for provenancing modern European oak wood using DNA extracted from sawdust. Deguilloux et al. (2003) optimised oak wood PCR amplification techniques by designing a set of nine primer pairs that target short cpDNA sequences (50-200 bp). Collectively, these targets distinguish nine common European cpDNA haplotypes, including those found in Britain. The authors successfully genotyped nine of 22 oak samples and compared these haplotypes with cpDNA maps to differentiate wood of western and eastern European origin. Using this method, Deguilloux et al. (2004) determined that haplotypes confirm the region of origin of wood used to manufacture oak barrels in the French cooperage industry.

Molecular investigations have identified that cpDNA in oak wood is rapidly degraded within the first few years after felling (Deguilloux et al. 2002; Dumolin-Lapegue et al. 1999). Deguilloux et al. (2002) characterised cpDNA degradation in oak logs as seen in amplifiable fragment lengths, and found that approximately 11 years after felling only segments less than $250 \mathrm{bp}$ could be amplified from the sapwood of logs. Despite these results, Dumolin-Lapegue et al. (1999) report amplification of $400 \mathrm{bp}$ of cpDNA from 600 year old oak wood from a dam, 
while Tani et al. (2003) amplified up to $600 \mathrm{bp}$ of nuclear DNA from 3600 year old Cryptomeria japonica wood that had also been buried in a dam. A review of previous wood DNA studies (see Table 1) indicates that DNA is increasingly degraded with age, resulting in smaller amplifiable fragments. It appears though that the level of DNA degradation becomes relatively stable after about two years after felling, with amplified fragments of 50 to $500 \mathrm{bp}$ in length. Our research aimed to build on the methods of these previous studies to extract and amplify cpDNA from waterlogged archaeological oak material from the Mary Rose, as part of a program to determine the geographic source of the timbers used in the ship's construction.

Table 1. Summary of previous oak cpDNA studies, indicating plant material, age and maximum fragment size amplified

\begin{tabular}{|l|l|l|l|}
\hline Tissue & $\begin{array}{l}\text { Age } \\
\text { (years) }\end{array}$ & $\begin{array}{l}\text { Size } \\
(\mathrm{bp})\end{array}$ & Reference \\
\hline $\begin{array}{l}\text { Leaf/ } \\
\text { Bud }\end{array}$ & Fresh & 1688 & Petit et al. 2002 \\
\hline Wood & 1 & 1483 & $\begin{array}{l}\text { Deguilloux et al. } \\
2002\end{array}$ \\
\hline Wood & 2 & 566 & $\begin{array}{l}\text { Deguilloux et al. } \\
2002\end{array}$ \\
\hline Wood & 3 & 175 & $\begin{array}{l}\text { Deguilloux et al. } \\
2002\end{array}$ \\
\hline Wood & 11 & 187 & $\begin{array}{l}\text { Deguilloux et al. } \\
2002\end{array}$ \\
\hline Wood & 300 & 350 & $\begin{array}{l}\text { Dumolin-Lapegue et } \\
\text { al. 1999 }\end{array}$ \\
\hline Wood & 3600 & 500 & Tani et al. 2003 \\
\hline
\end{tabular}

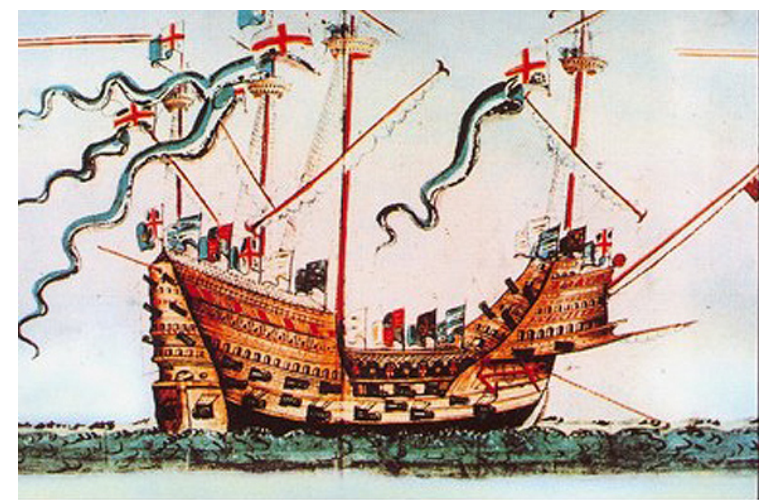

Figure 1. The Mary Rose as depicted on the Anthony Roll. This is the only known contemporaneous image of the ship. (Image courtesy of The Mary Rose Trust).

\section{THE MARY ROSE}

The Mary Rose (Figure 1) was built in Portsmouth, England, between 1509 and 1511 and served as the flagship of King Henry VIII's fleet until 1545, when she sank in the Solent Channel during a battle with the French (Bridge and Dobbs 1996; Marsden 2003). Lying on its starboard side, the hull filled with sediments that preserved this portion in an anoxic environment, while the exposed port side of the ship decayed (Mouzouras et al. 1986; Rule 1983). Constructed almost entirely of oak (Quercus spp.), the remains of the ship were raised from the seabed in 1982 (Rule 1983; The Mary Rose Trust 2002) and are currently being conserved with a warm polyethylene glycol (PEG) spray solution (Figure 2). This treatment will prevent shrinkage when the timbers are dried out, starting in 2011 (The Mary Rose Trust 2002).

As the conservation program to stabilise the timbers nears completion, a number of important questions remain unanswered, including confirmation of the assumed source of the timber used in her construction and later refit. Contemporaneous documents relating specifically to timber supply for the Mary Rose have not been found. Clues to the source of the wood are restricted to documents recording that timber for contemporaneous ships was purchased local to Portsmouth (within $50 \mathrm{~km}$ ). The ship also had at least one major refit in 1536, probably in the River

Medway at Chatham (Figure 3). Royal accounts indicate that timber used for ship rebuilding in the River Medway was purchased from southeast England (Bridge and Dobbs 1996).

Cottrell et al. (2002) and Lowe et al. $(2004,2006)$ have constructed a detailed oak cpDNA haplotype distribution map of Britain (Figure 4) that may be used to match haplotypes from oak timbers of the Mary Rose with their presumed region of origin. These authors found that the dominant haplotypes of Britain are those known as 10,11 and 12. According to this map, oak populations around the Portsmouth region are dominated by haplotype 10, whereas the majority of southeast populations, near Chatham, are haplotype 12. Thus, timbers from the original 


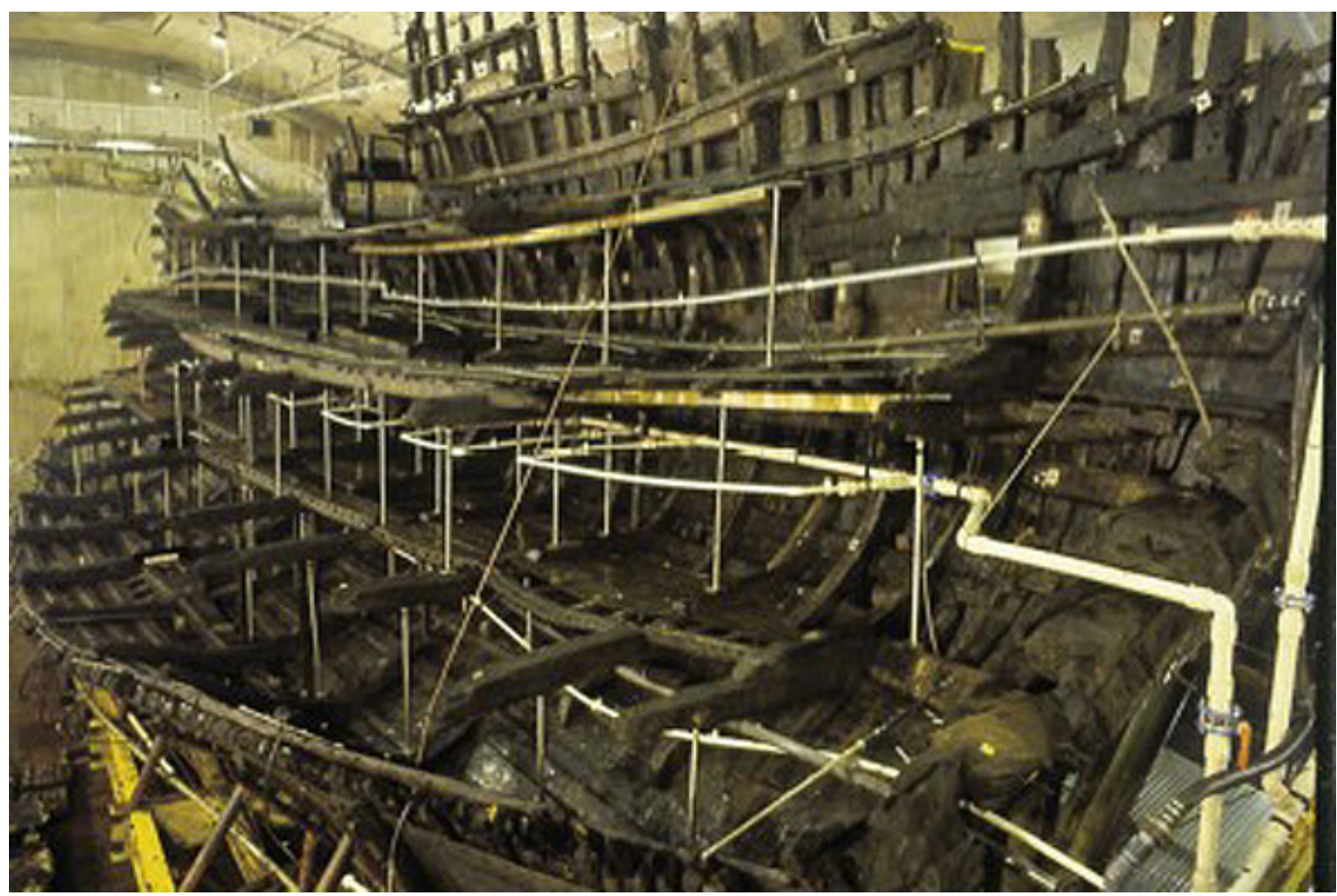

Figure 2. Salvaged starboard side of the Mary Rose on display in a dry dock in Portsmouth. The ship's remains were excavated in 1982 and are currently being conserved with a warm spray solution of the water-soluble wax polyethylene glycol (PEG). (Reproduced with permission from The Mary Rose Trust).

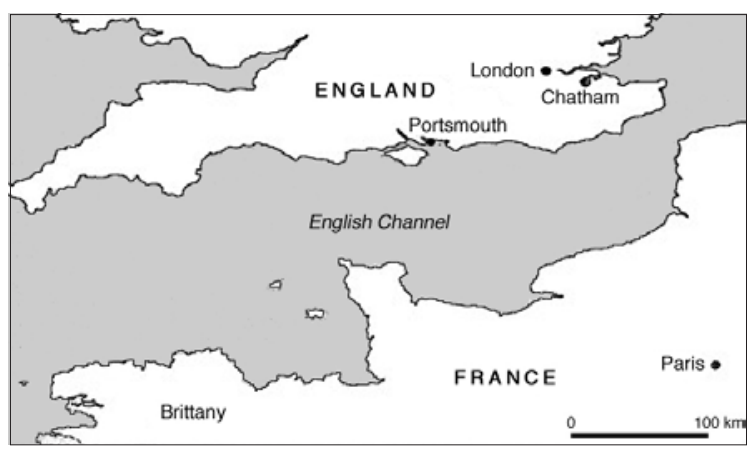

Figure 3. England and northern France identifying Portsmouth and Chatham. The Mary Rose was built in Portsmouth (15091511) and had at least one major refit (1536), probably in the River Medway near Chatham. The ship sank about $1 \mathrm{~km}$ from Portsmouth in the Solent. (Adapted from Bridge and Dobbs 1996). construction of the Mary Rose would most likely be haplotype 10 , whereas refit timbers would be haplotype 12 . While positive correlation of the genetic signatures of the Mary Rose timbers with those of regional oak populations would not prove their source, failure to correlate would definitively exclude non-matching oak populations. As Stage I in a long-term project to genetically map the provenance of the Mary Rose timbers, existing cpDNA extraction protocols were assessed for their applicability to the specific archaeological circumstances surrounding the ship's taphonomic history, and new procedures were developed when necessary.

\section{MATERIALS AND METHODS}

DNA from the Mary Rose oak wood was expected to be extremely low in quantity and quality, therefore in this study production of target PCR product was considered primary proof of successful DNA extraction, while the production of primer dimer confirmed appropriate PCR conditions in the absence of DNA. Successfully amplifying cpDNA required a series of experimental modifications to established protocols. These steps are outlined in the methods and results sections below in the sequence in which 


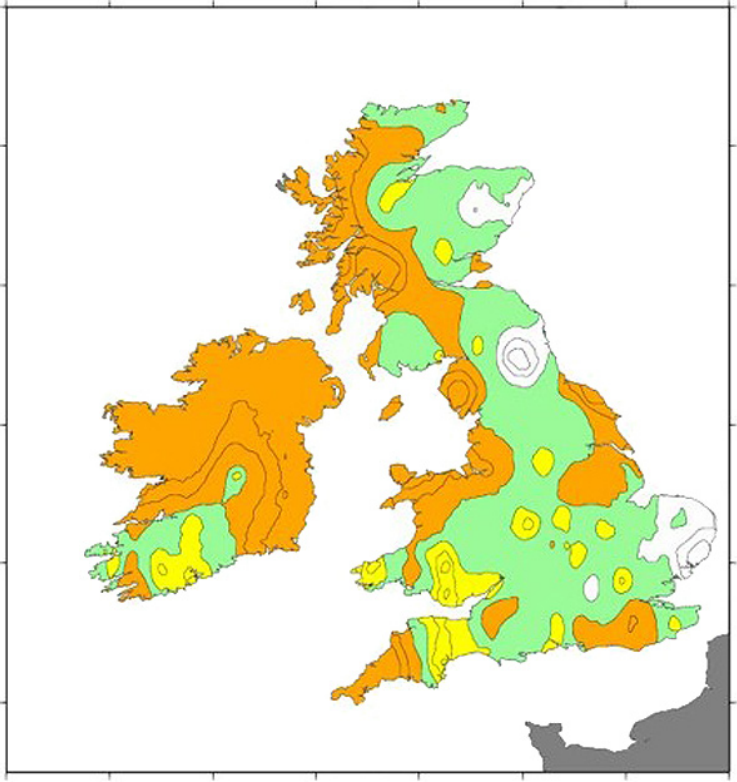

Figure 4. Distribution of three most common oak cpDNA haplotypes across the British Isles. Key: haplotype $10=$ yellow, $11=$ white and $12=$ orange. A kriging average of cpDNA haplotype frequency is presented, where green are regions of no overall dominance and the outer circles of the three representative haplotype colours indicate where that type is found within neighbouring populations at a frequency greater that $60 \%$; additional concentric lines within these areas represent haplotype dominances of 80 and $100 \%$. Portsmouth and Chatham areas are dominated by haplotypes 10 and 12 respectively. (Modified from Lowe et al. 2006). two thirds of the core weight to the sandpaper grit matrix. An alternative method of producing sawdust using a mini hacksaw substantially reduced sample waste. Sawdust was transferred to a $1.5 \mathrm{ml}$ sealed plastic tube, weighed and stored at $-20^{\circ} \mathrm{C}$.

\section{CONTAMINATION CONTROL}

In aDNA research it is essential to avoid contamination of reagents with modern DNA (Cooper and Poinar 2000; Pääbo et al. 2004). Precautions applied in this study included performing all ancient and modern experiments in separate laboratories at the University of Queensland (UQ) and treating all equipment and workspaces with a bleach solution. All mobile equipment was irradiated with ultraviolet (UV) light to mutate contaminant DNA and we monitored reagent and laboratory contaminants by including negative controls (extractions and PCR amplifications performed without adding DNA). Mary Rose sample sawdust was prepared in the Archaeological Sciences Laboratory (ASL) UV room after irradiating the room for at least 10 minutes. Aliquots of reagents used in aDNA PCR amplifications were prepared in the ASL airflow displacement bubble. All modern oak work was performed in the UQ Life Sciences Laboratory, located in a different building to the ASL. 


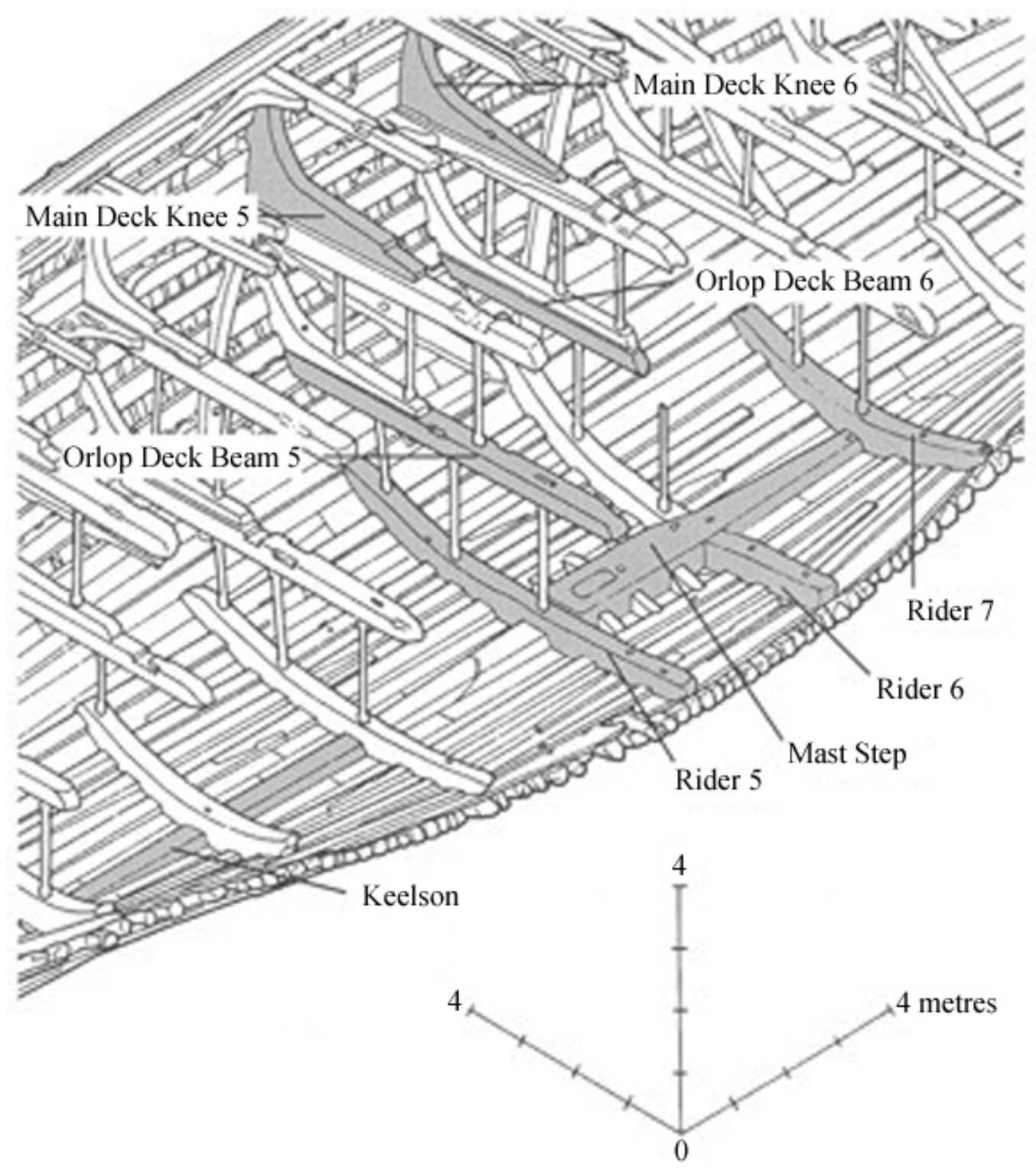

Figure 5. An isometric diagram of the Mary Rose hull showing the location of timbers (shaded) sampled for this study. The key lists the sampled timbers and their correlating reference label used in this study. As each timber has been sampled twice, individual cores from each timber are designated $A$ and B. (Reproduced with permission from The Mary Rose Trust).

\section{PREVIOUSLY PUBLISHED METHODS}

DNA extractions were performed using the DNeasy Plant Minikit (Qiagen) as per Deguilloux et al. (2003). To increase the weight of the starting sample to a comparable 80-100 $\mathrm{mg}$, we combined five separate $20 \mathrm{mg}$ extractions through a single spin column.

DNA extracts were used in PCR amplifications according to the protocol of Demesure et al. (1995), which was also used for wood DNA by Deguilloux et al. (2003). PCR was conducted using five primer pairs designed by Deguilloux et al. (2003): tf42, $\mu \mathrm{dt} 1, \mathrm{dt} 13, \mathrm{dt} 74$ and dt74b. These primer pairs were chosen because they target cpDNA sequences less than $100 \mathrm{bp}$ that contain informative polymorphisms and collectively differentiate amongst the four common British Quercus haplotypes 7, 10,11 and 12 (after Cottrell et al. 2002). PCR products were separated by $3 \%$ agarose gel electrophoresis and PCR product was labelled with early termination (ET) dye for sequencing using the MegaBACE 1000 (Amersham Biosciences). 


\section{DETECTION OF PCR INHIBITORS IN MARY ROSE DNA EXTRACTS}

Mary Rose sawdust samples extracted using the above methods failed to produce product or primer dimer following amplification. To verify that amplification failure was due to the presence of PCR inhibitors rather than the PCR conditions, we added modern DNA to the reactions (Bickley and Hopkins 1999). According to this method, modern DNA is added to the positive control and the Mary Rose extract. Successful amplification of the modern product in the positive control but not the Mary Rose extract indicates PCR inhibition.

Initially we used $2 \mu 1 \mathrm{pUC19}$, an Escherichia coli plasmid (Yanisch-Perron et al. 1985), to detect PCR inhibition in Mary Rose extracts. These PCR amplifications were performed using primers Af and $\mathrm{Cr}$ to amplify a $217 \mathrm{bp}$ fragment (Connell 2002). We used modern oak wood DNA instead of the plasmid during subsequent PCR optimisation experiments,.

Extracts were assessed for nucleic acid quantity and purity with the NanoDrop ND-1000 spectrophotometer. Nucleic acids were measured at an absorbency of $260 \mathrm{~nm}$ and the quantity of DNA in each sample was calculated in $n g / \mu l$. Protein and phenols were measured at absorbencies of 280 and $230 \mathrm{~nm}$. To assess the purity of DNA, the NanoDrop software calculates the ratio of absorbance at 260 and $280 \mathrm{~nm}(260 / 280)$ and at 260 and $230 \mathrm{~nm}(260 / 230)$, where pure DNA has a $260 / 280$ ratio of $\sim 1.8$ and a $260 / 230$ ratio within the range of $1.8-2.2$. The information obtained was used to characterise potential PCR inhibitors in the Mary Rose extracts.

\section{MODIFICATION OF PREVIOUSLY PUBLISHED METHODS}

Two modifications of the lysis stage of the extraction method were trialled on samples HT4 and MD1. These changes were based on the protocol of Guy et al. (2003): (1) adding Proteinase K (Boehringer Mannheim) to the lysis stage; and (2) adding Proteinase K, Chelex 100 (BioRad) and polyvinylpyrrolidone (PVP) 360 (Sigma). Proteinase K digests proteins, PVP360 sequesters phenolics and Chelex 100 is an ion chelating resin (Guy et al. 2003).

\section{NEW MARY ROSE EXTRACTION PROTOCOL}

DNA was extracted from Mary Rose samples using a new protocol developed from the methods of Guy et al. (2003) and adapted to the DNeasy Plant Minikit protocol. $100 \mathrm{mg}$ of dry sawdust from a single Mary Rose timber sample was divided into five extraction tubes of $20 \mathrm{mg}$ each. To each of the five individual extractions, $10 \mu 1$ of $20 \mathrm{mg} / \mathrm{ml}$ Proteinase $\mathrm{K}$ was added to the lysis stage incubation, which was lowered to $55^{\circ} \mathrm{C}$ and extended to $1 \mathrm{hr}$. Cellular debris was pelleted by centrifugation for $5 \mathrm{~min}$ at 14,000 rpm. The supernatant liquid was transferred to a sterile tube and incubated for $30 \mathrm{~min}$ at $55^{\circ} \mathrm{C}$ with $0.1 \mathrm{~g}$ of Chelex 100 and $125 \mu 1$ of an $8 \%$ PVP 360 solution. The PVP 360 solution was made in lysis buffer AP1 (DNeasy Plant Minikit) and incubated for one hour at $55^{\circ} \mathrm{C}$ to dissolve.

Following the detergent precipitation stage, the sample was centrifuged for $10 \mathrm{~min}$ at 14,000 rpm and the supernatant liquid applied to the shredder column. After buffer AP3/E (DNeasy Plant Minikit) was added to each individual extract, the solution from all five tubes for a single timber sample was applied to a single spin column. The DNA was eluted in $100 \mu 1$ buffer AE (DNeasy Plant Minikit) and stored overnight at $-20^{\circ} \mathrm{C}$ before being used as template in PCR amplifications. This new method was performed on five Mary Rose samples (HT1, HT2, HT3, OD1 and OD2). PCR was performed using the Mary Rose extracts HT3 and OD2 in template volumes that ranged from 0.5 to $5 \mu 1$ to assess the effect on amplification success.

The efficiency of the new Mary Rose DNA extraction protocol was tested using known quantities of modern oak wood DNA. A modern oak extract with a DNA concentration of 9.26 $\mathrm{ng} / \mu \mathrm{l}$ (Table 2) was used to make a dilution series of 100, 50, 20, 10, 5, 2 and $1 \%$. One hundred microlitres of each dilution, equating to $926,463,185.2,92.6,46.3,18.52$ and 9.26 ng of DNA respectively, was added to extractions instead of sawdust and tested with PCR. 


\section{MODIFIED MARY ROSE PCR PROTOCOL}

The presence of primer dimer in reactions without DNA indicates appropriate PCR conditions. As the PCR protocol of Demesure et al. (1995) was unreliable in producing primer dimer, we adopted the ASL PCR protocol. This protocol includes excess primer to promote primer dimer formation in reactions without DNA, AmpliTaq DNA Polymerase Stoffel Fragment to reduce the production of false positive results (Loy 1997) and 5\% dimethyl sulfoxide (DMSO), which has been shown to reduce PCR inhibition caused by some acidic plant substances (Bickley and Hopkins 1999). For a single $50 \mu 1$ reaction with $2 \mu \mathrm{l}$ DNA template, the ASL protocol includes $29 \mu 1$ Milli-Q water, $8 \mu 1 \mathrm{MgCl}_{2}, 5 \mu 1$ 10x Stock Buffer, $2.5 \mu 1$ 100\% DMSO, $1 \mu 1$ each $10 \mathrm{mM}$ 5' primer, 3' primer and dNTP's and $0.5 \mu 1$ AmpliTaq DNA Polymerase Stoffel Fragment.

Following the successful reduction of PCR inhibition from five Mary Rose DNA extracts, the ASL PCR protocol was optimised. Extracts were centrifuged for $15 \mathrm{~min}$ at 14,000 rpm and PCR template was extracted from the top aqueous layer to avoid residual Chelex 100, which inhibits polymerase. $10 \mu \mathrm{l}$ Q-solution (Qiagen) was added, with a subsequent reduction in Milli-Q water. The 50-cycle PCR denaturation temperature was raised to $94^{\circ} \mathrm{C}$ and the elongation time was reduced to $45 \mathrm{sec}$ to increase the efficiency of these stages. Also, the annealing temperature of primer pairs dt74 and dt 13 was increased to $50^{\circ} \mathrm{C}$ and primer pairs tf 42 and $\mu \mathrm{dt} 1$ to $55^{\circ} \mathrm{C}$.

\section{RESULTS}

\section{Modern wood}

Using the methods of Deguilloux et al. (2003), all five primer pairs tested with modern oak wood DNA successfully produced a single band of expected fragment size.

\section{Trial of previously published protocols on Mary Rose samples}

The major cell wall components of wood tissue, such as carbohydrates (cellulose) and phenols (lignin) (Finney and Jones 1993; Levy 1977) are PCR inhibiting substances (Bickley and Hopkins 1999; Gugerli et al. 2005). Previous research has established that degradative processes have increased the iron content of the Mary Rose hull timbers, which also inhibits PCR (Finney and Jones 1993; Squirrell and Clarke 1987). Initial extraction of Mary Rose samples caused a strong yellow or brown discolouration of the DNeasy spin column membrane and elution. PCR amplification of these DNA extracts resulted in no detectable product or primer dimer. When tested with pUC19 DNA, the plasmid target fragment was amplified in the positive DNA control and primer dimer was amplified in the negative DNA control. In contrast, no product or primer dimer was produced in the presence of $2 \mu 1$ Mary Rose extract, indicating the presence of PCR inhibitors.

Table 2 shows the results of NanoDrop assays for oak DNA extracted from modern wood and from Mary Rose samples. Sample HT4 Proteinase K had the largest amount of DNA at 129.39 $\mathrm{ng} / \mu \mathrm{l}$. Half of the samples had less than $45 \mathrm{ng} / \mu \mathrm{l}$ and three of those had less than $10 \mathrm{ng} / \mu \mathrm{l}$. This latter category includes a modern DNA sample, which had $9.26 \mathrm{ng} / \mu 1$. Most of the Mary Rose DNA samples had 260/280 and 260/230 absorbance ratios substantially below 1.8-2.2, indicating the presence of contaminants that absorb at 280 and 230 such as protein or phenol. The modern DNA extract had the highest 260/280 ratio of 1.42. A sample of HT5 Proteinase K had a 260/230 ratio of 1.76 , however this sample also had an extremely low $260 / 280$ ratio of $<0.95$, suggesting that contaminants were present in this sample and that the DNA purity is still very poor.

\section{Modification of previously published methods}

Both modifications based upon the method of Guy et al. (2003) were successful in removing the discolouration of the spin column membrane and subsequent DNA elution. However, only the second treatment that included Proteinase K, Chelex 100 and PVP360 successfully removed 
Table 2. NanoDrop results for modern and archaeological oak wood DNA samples. Alternative extraction treatments are listed with Mary Rose sample labels. Nucleic acids are measured at an absorbance of $260 \mathrm{~nm}$ and the quantity of DNA is measured in $\mathrm{ng} / \mu \mathrm{l}$. The 260/280 and 260/230 ratio values indicate the purity of DNA in each sample, where pure DNA has values of $\sim 1.8$ and 1.8-2.2 respectively

\begin{tabular}{|c|c|c|c|c|}
\hline Sample & DNA (ng/ul) & $\mathbf{A 2 6 0}$ & $\mathbf{2 6 0 / 2 8 0}$ & $\mathbf{2 6 0 / 2 3 0}$ \\
\hline Modern & 9.26 & 0.18 & 1.42 & 0.46 \\
\hline HT2A & 11.78 & 0.24 & 0.88 & 0.39 \\
\hline HT4A & 104.14 & 2.08 & 0.86 & 1.5 \\
\hline HT5A & 75.24 & 1.5 & 0.78 & 1.22 \\
\hline MD1A & 57.73 & 1.15 & 0.75 & 1.65 \\
\hline $\begin{array}{c}\text { HT5A } \\
\text { Proteinase K }\end{array}$ & 129.39 & 2.788 & 0.82 & 1.76 \\
\hline $\begin{array}{c}\text { MD1A } \\
\text { Proteinase K }\end{array}$ & 32.63 & 0.65 & 0.94 & 0.89 \\
\hline $\begin{array}{c}\text { MD1A } \\
\text { Chelex 100/PVP360 }\end{array}$ & 2.6 & 0.05 & 0.88 & -0.78 \\
\hline $\begin{array}{c}\text { HT4A } \\
\text { Chelex 100/PVP360 }\end{array}$ & 4.9 & 0.1 & 1.29 & -3.32 \\
\hline
\end{tabular}

inhibition from sample MD1A, as demonstrated by the presence of primer dimer after amplification. Despite this removal, no target DNA was amplified from this sample.

\section{New Mary Rose extraction protocol}

Five Mary Rose samples (HT1, HT2, HT3, OD1 and OD2) were subjected to the new Mary Rose extraction protocol. Production of primer dimer in PCR amplifications of all five extracts indicated that the inhibiting substances had been removed. This was confirmed by the successful amplification of modern oak cpDNA 'spiked' into $5 \mu 1$ of the Mary Rose extracts MD1 and HT4.

The efficiency of this new method was tested with a dilution series of modern oak wood DNA. Figure 6 illustrates that PCR product and primer dimer is visible in all test lanes in intensities inversely proportional to the quantity of DNA added. Primer dimer is also visible in the negative DNA extract and PCR controls. These results demonstrate that as little as $9.26 \mathrm{ng}$ of DNA was extracted successfully using the new extraction protocol, amplified with primer pair dt74 and visualised on a $3 \%$ agarose electrophoresis gel.

Finally, volumes of Mary Rose DNA ranging between 0.5 and $5 \mu 1$ were used in PCR amplifications with two sets of primers to assess whether template volume affected amplification success. As illustrated in Figure 7, primer dimer was produced in all test reactions, while PCR product dt74b was amplified from 0.5 and $1 \mu 1$ of OD2 template. Subsequent PCR amplifications using 0.5 and $1 \mu 1$ Mary Rose OD2 DNA template with each primer pair successfully amplified fragment $\mathrm{dt} 74 \mathrm{~b}$ again, and also fragment tf42.

\section{DISCUSSION}

\section{Previously published methods}

Application of the methods of Deguilloux et al. (2003) to Mary Rose samples resulted in a discoloured spin column membrane indicating the co-elution of PCR inhibitors. This conclusion was supported by the failure to produce product or primer dimer. To distinguish between inhibition and reaction failure, the ASL PCR protocol was adopted to encourage primer dimer production in successful PCR amplifications that do not contain DNA. The presence of PCR inhibitors in Mary Rose extracts was confirmed by the modern DNA inhibition test using pUC19 (Bickley and Hopkins 1999; Connell 2002; Yanisch-Perron et al. 1985). According to these results, the methods of Deguilloux et al. (2003) were not adequate for extraction and amplification of DNA 


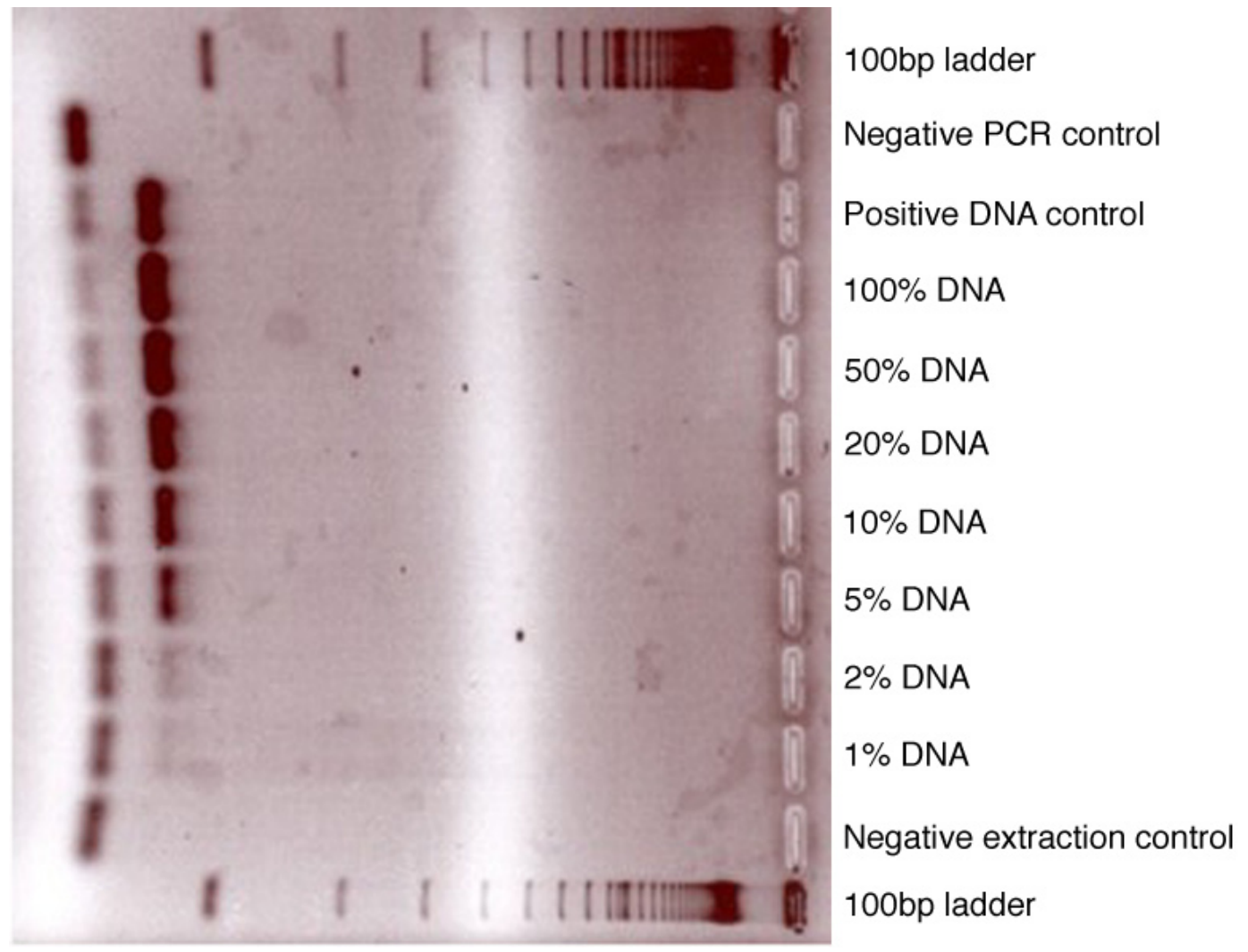

Figure 6. Inverse transillumination image of PCR products from the quantified test of the Mary Rose DNA extraction protocol. This amplification was conducted with DNA extracted from a dilution series of modern oak DNA. Primer dimer is observed in all lanes. PCR product of the expected size can be seen in all test reactions, where it occurs in an inversely proportionate intensity to the primer dimer band, depending on the percentage of DNA added.

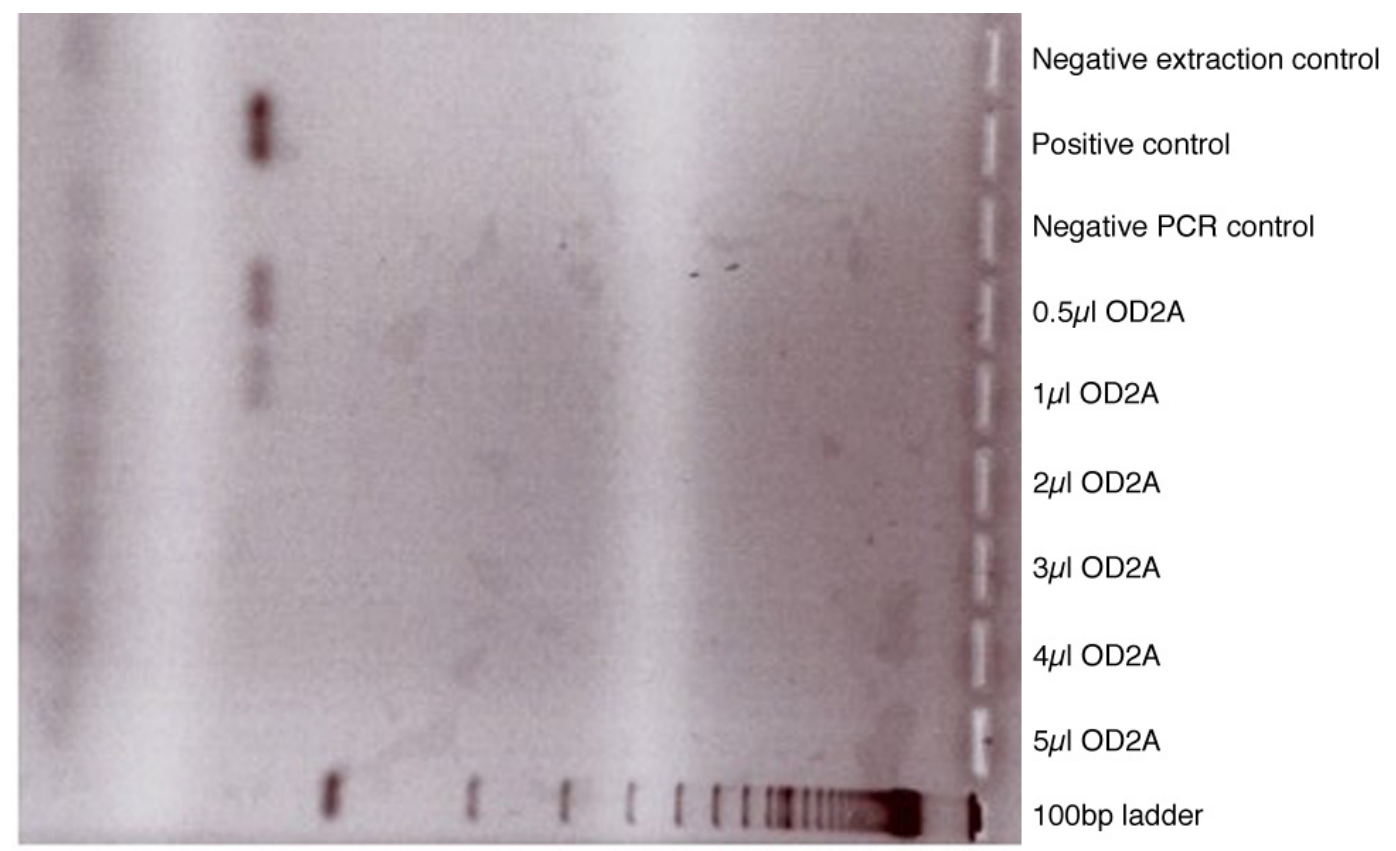

Figure 7. Mary Rose DNA. Inverse transillumination image of PCR products from amplifications using Mary Rose template volumes ranging between 0.5 to $5 \mu$. Primer dimer can be seen in all reactions except the positive DNA control. PCR products can be seen in the positive DNA control and in amplifications with 0.5 and $1 \mu \mathrm{l}$ of OD2A template. 
from the Mary Rose wood. Therefore, to progress the research it was necessary to characterise and determine how to remove the PCR inhibitors.

To characterise inhibitors we used the NanoDrop ND-1000 to determine the quantity and purity of DNA present in the Mary Rose extracts. Results from this analysis confirmed the expected low quantity and quality of DNA and indicated a high concentration of substances that absorb at wavelengths of 230 and $280 \mathrm{~nm}$, most probably proteins and phenols.

Failure to amplify DNA due to inhibition does not necessarily mean that there is no DNA present. One approach to removing PCR inhibition is to dilute the extract prior to PCR. This method reduces the amount of inhibitors to a concentration tolerable to PCR, with a concurrent reduction in DNA template quantity (Bickley and Hopkins 1999). Although this method was successfully used by Tani et al. (2003) and Deguilloux et al. (pers. comm) when using aDNA samples it is imperative to maximise the concentration of PCR template in every reaction. Therefore, rather than reducing the amount of aDNA extract added to PCR, protocol modifications were designed to reduce PCR inhibitors such as iron and phenols during DNA extraction with the DNeasy Plant Minikit protocol.

\section{Modification of previously published methods}

Adding Proteinase $\mathrm{K}$ to the lysis stage to digest the proteins that appeared to be co-extracted with the Mary Rose DNA successfully removed the discolouration of the spin column membrane and elution, but did not remove PCR inhibition. These results suggested that the removal of extra protein made an improvement in the quality of the extraction, however proteins were not the sole cause of inhibition. Proteinase K treatment, followed by incubation with Chelex 100 and PVP360 was trialled and successfully produced primer dimer in the Mary Rose MD1 DNA reaction.

Chelex 100 was added as a multivalent ion chelating resin that targets metals such as iron and PVP360 was added to remove phenolics from the lysis solution by forming PVP/phenol complexes. These results indicate that the PCR inhibiting substances were a combination of protein, iron and phenolics. Furthermore, the enhanced amplification efficiency with these extracts after centrifugation suggested that the PCR may have been affected by residual Chelex 100. Successful amplification of modern oak DNA used to 'spike' $5 \mu 1$ of these aDNA extracts demonstrated that PCR inhibiting substances had been removed.

\section{New Mary Rose extraction protocol}

The new protocol involves lysis stage treatments, as well as an increased starting sample size and optimised PCR conditions. A quantified test of the new protocol demonstrated that this method was efficient in extracting and amplifying as little as $9.26 \mathrm{ng}$ of modern oak DNA from extracts.

This new protocol was tested on five Mary Rose samples (HT1, HT2, HT3, OD1 and OD2) and primer dimer was successfully amplified from $5 \mu$ of each extract. Two of these extracts (HT3 and OD2) were then used in a series of amplifications with template volumes ranging from 0.5 to $5 \mu \mathrm{l}$. The target $\mathrm{dt} 74 \mathrm{~b}$ product was amplified from the smaller volumes $(0.5$ and $1 \mu \mathrm{l})$ of extract OD2 (Figure 7). This is the first extraction and amplification of cpDNA from waterlogged archaeological oak wood from a marine environment, and represents a significant advance towards the potential geographic provenancing of the Mary Rose timbers.

These results demonstrated that primer dimer and modern DNA products could be produced in the presence of up to $5 \mu \mathrm{l}$ of Mary Rose extracts using this method. However, inhibiting substances were still present in the Mary Rose extracts, preventing amplification of product from more than $1 \mu \mathrm{l}$ of these extracts. These findings suggest that some residual inhibitors may be closely associated with the DNA itself, however the concentration is tolerable to PCR at these lower volumes. Subsequent amplifications with 0.5 and $1 \mu 1$ of three Mary Rose samples (HT3, OD1 and OD2) replicated the amplification of fragment dt74b from the OD2 extract, as well as fragment tf42. With the success of Stage I the next stages of this project can now proceed with sequencing of the amplified cpDNA fragments and comparison with geographic haplotype data. 


\section{Contamination or Mary Rose DNA?}

Several arguments support the conclusion that the PCR products obtained were the target oak cpDNA fragments and not contaminating DNA from another source. First, throughout this study, PCR products of the expected size were consistently amplified from oak DNA from multiple extractions and using different reagents, suggesting that these fragments were in fact the target oak cpDNA products. This finding is supported by the use of primer pairs designed to be specific to oak cpDNA and used successfully in previous studies. It is highly unlikely that each extraction or PCR tube was affected by a contaminant that consistently amplified fragments of the expected size.

Second, Mary Rose sample OD2A PCR amplifications may have been contaminated with unknown DNA or modern oak wood DNA that were transferred into the ASL. In the first amplification of Mary Rose OD2 DNA (Figure 7), the $0.5 \mu 1$ template was the first to be loaded into the PCR tube and the $1 \mu \mathrm{l}$ template reaction was the last extract loaded. Thus, if the products were amplified from aerosol contaminants entering individual tubes, it is unlikely that it would demonstrate such a regular dispersal. It seems more likely that aerosol contamination would affect reactions in a mosaic pattern, as well as affecting at least one negative DNA control. Furthermore, in all amplifications using Mary Rose DNA extracts, the products only occur in the OD2A reactions.

It is more likely, given the pattern of occurrence, that if successful reactions were caused by contaminating DNA then it would have entered the OD2 extract itself. However, DNA was only amplified from Mary Rose extract OD2 when added at amounts of 0.5 and $1 \mu 1$, indicating that residual inhibitors were affecting the PCR amplification at larger template volumes. Alternatively, modern oak DNA added to reactions with $5 \mu 1$ of Mary Rose extract still amplified fragments of the expected size. This supports the assumption that the PCR inhibitors may be linked with the Mary Rose DNA itself, and so modern contaminant DNA would have amplified in all the Mary Rose template volumes (up to $5 \mu \mathrm{l}$ ). These results support the conclusion that the products amplified from the OD2 extract are in fact fragments of Mary Rose cpDNA.

\section{CONCLUSION}

The aims of this study were to evaluate current methods of cpDNA analysis for their suitability to the specific archaeological case of the waterlogged Mary Rose timbers, and to develop procedures that would enable successful recovery of cpDNA from these samples. Chloroplast DNA was successfully extracted and amplified from modern and Mary Rose oak, demonstrating the viability of the new Mary Rose extraction protocol. These results are an encouraging start to the project aimed at determining the provenance of the flagship's timbers. The next stages will focus on sequencing the cpDNA fragments to verify the identity of the DNA. The extraction, amplification and sequencing results will then be replicated in an independent laboratory to support the authenticity of these fragments. Finally, the haplotype of each sample will be determined from these sequences for provenancing studies. The successful provenancing of these timbers would contribute significantly to our historical understanding of the archaeological remains of the Mary Rose.

On a broader scale, the successful extraction and amplification of DNA from archaeological oak wood offers the prospect of recovering unique and direct evidence of the genetic structure of Quercus spp. populations in the past. The Mary Rose DNA extraction protocol presents a technique for reducing PCR inhibitors from archaeological oak samples without dilution of the extract, thus maximising the concentration of DNA template available for analysis. Inhibition removal methods trialled in the development of this protocol have increased our understanding of different methods of reducing PCR inhibition in DNA extracts from waterlogged archaeological oak wood. This protocol and the lessons learnt in the current study broaden the range of tools and documented experience available to ancient DNA researchers, and expand the range of archaeological artefacts that can be examined for palaeogenetic information. 


\section{ACKNOWLEDGEMENTS}

For permissions and assistance the authors would like to thank the Mary Rose Trust, the University of Queensland (UQ) Life Sciences Laboratory, the UQ Archaeological Sciences Laboratory and Dr Tom Loy.

\section{REFERENCES}

Bickley, J. and D. Hopkins 1999. Inhibitors and enhancers of PCR. In G.C. Saunders and H.C. Parkes (eds) Analytical Molecular Biology Quality and Validation, Supplement 190, pp. 81-102. Redwood Books Ltd.

Brewer, S., R. Cheddadi, J.L. de Beaulieu and M. Reille 2002. The spread of deciduous Quercus throughout Europe since the last glacial period. Forest Ecology And Management 156(13):27-48.

Bridge, M.C. and C. Dobbs 1996. Tree-ring studies on the Tudor warship Mary Rose. In Eds: J.S. Dean, D.M. Meko and T.W. Swetnam (eds) Tree Rings, Environment and Humanity, pp. 491-496. Tucson: Radiocarbon.

Capelli, C., F. Tschentscher and V.L. Pascali 2003. "Ancient" protocols for the crime scene? Similarities and differences between forensic genetics and ancient DNA analysis. Forensic Science International 131(1):59-64.

Connell, J. 2002. Towards the Repair of Ancient DNA and Using the Damaged Plasmid Model as an Intra- and Inter-Laboratory Control. Unpublished ms on file. Brisbane: Department of Biochemistry, University of Queensland.

Cooper, A. and H. Poinar 2000. Ancient DNA: do it right or not at all. Science 289:1139.

Cottrell, J.E., R.C. Munro, H.E. Tabbener, A.C.M. Gillies, G.I. Forrest, J.D. Deans and A.J. Lowe 2002. Distribution of chloroplast DNA variation in British oaks (Quercus robur and Q-petraea): the influence of postglacial colonisation and human management. Forest Ecology And Management 156(1-3):181-195.

Deguilloux, M.F., M.H. Pemonge, L. Bertel, A. Kremer and R.J. Petit 2003. Checking the geographical origin of oak wood: molecular and statistical tools. Molecular Ecology 12(6):1629-1636.

Deguilloux, M.F., M.H. Pemonge and R.J. Petit 2002. Novel perspectives in wood certification and forensics: dry wood as a source of DNA. Proceedings Of The Royal Society Of London Series B 269(1495):1039-1046.

Deguilloux, M.F., M.H. Pemonge and R.J. Petit 2004. DNA-based control of oak wood geographic origin in the context of the cooperage industry. Annals Of Forest Science 61(1):97-104.

Demesure, B., N. Sodzi and R.J. Petit 1995. A set of universal primers for amplification of polymorphic noncoding regions of mitochondrial and chloroplast DNA in plants. Molecular Ecology 4(1):129-131.

Dumolin-Lapegue, S., B. Demesure, S. Fineschi, V. LeCorre and R.J. Petit 1997. Phylogeographic structure of white oaks throughout the European continent. Genetics 146(4):1475-1487.

Dumolin-Lapegue, S., M.H. Pemonge, L. Gielly, P. Taberlet and R.J. Petit 1999. Amplification of oak DNA from ancient and modern wood. Molecular Ecology 8(12):2137-2140. 
Ferris, C., R.P. Oliver, A.J. Davy and G.M. Hewitt 1993. Native oak chloroplasts reveal an ancient divide across Europe. Molecular Ecology 2(6):337-344.

Ferris, C., R.P. Oliver, A.J. Davy and G.M. Hewitt 1995. Using chloroplast DNA to trace postglacial migration routes of oaks into Britain. Molecular Ecology 4(6):731-738.

Finney, R.W. and A.M. Jones 1993. Direct analysis of wood preservatives in ancient oak from the Mary Rose by laser microprobe mass spectrometry. Studies in Conservation 38:36-44.

Gugerli, F., L. Parducci and R.J. Petit 2005. Ancient plant DNA: review and prospects. New Phytologist 166(2):409-418.

Guy, R.A., P. Payment, U.J. Krull and P.A. Horgen 2003. Real-time PCR for quantification of Giardia and Cryptosporidium in environmental water samples and sewage. Applied And Environmental Microbiology 69(9):5178-5185.

Hewitt, G.M. 1999. Post-glacial re-colonization of European biota. Biological Journal Of The Linnean Society 68(1-2):87-112.

Hofreiter, M., D. Serre, H.N. Poiner, M. Kuch and S. Pääbo 2001. Ancient DNA. Nature Reviews Genetics 2(5):353-359.

Hoss, M., P. Jaruga, T.H. Zastawny, M. Dizdaroglu and S. Pääbo 1996. DNA damage and DNA sequence retrieval from ancient tissues. Nucleic Acids Research 24(7):1304-1307.

Huntley, B. and H.J.B. Birks 1983. An Atlas of Past and Present Pollen Maps of Europe, 0-13,000 Years Ago. Cambridge: Cambridge University Press.

Levy, J.F. 1977. Degradation of wood. In S. McGrail (ed.) Sources and Techniques in Boat Archaeology, pp. 15-22. BAR Supplementary Series 29. Oxford:British Archaeological Reports.

Lindahl, T. 1993. Instability and decay of the primary structure of DNA. Nature 362(6422):709715.

Lowe, A., R. Munro, S. Samuel and J. Cottrell 2004. The utility and limitations of chloroplast DNA analysis for identifying native British oak stands and for guiding replanting strategy. Forestry 77(4):335-347.

Lowe, A.J., C. Unsworth, S. Gerber, S. Davies, R.C. Munro, C. Kelleher, A. King, S. Brewer, A. White and J. Cottrell 2006. The route, speed and mode of oak postglacial colonisation across the British Isles: integrating molecular ecology, palaeoecology and modelling approaches. Botanical Journal of Scotland 57:59-82.

Loy, T. 1997. Ultrapure water, is it pure enough? Ancient Biomolecules 1:155-159.

Marsden, P. 2003. Sealed by Time: The loss and recovery of the Mary Rose. Trowbridge: Cromwell Press.

Mouzouras, R., E.B.G. Jones, R. Venkatasamy and S.T. Moss 1986. Decay of wood by microorganisms in marine environments. Record of the 1986 Annual Convention of the British Wood Preserving Association: 27-45.

Pääbo, S. 1989. Ancient Dna - Extraction, Characterization, Molecular-Cloning, And Enzymatic Amplification. Proceedings Of The National Academy Of Sciences 86(6):1939-1943.

Pääbo, S., H. Poinar, D. Serre, V. Jaenicke-Despres, J. Hebler, N. Rohland, M. Kuch, J. Krause, L. Vigilant and M. Hofreiter 2004. Genetic analyses from ancient DNA. Annual Review Of Genetics 38: 645-679. 
Petit, R.J., S. Brewer, S. Bordacs, K. Burg, R. Cheddadi, E. Coart, J. Cottrell, U.M. Csaikl, B. van Dam, J.D. Deans, S. Espinel, S. Fineschi, R, Finkeldey, I. Glaz, P.G. Goicoechea, J.S. Jensen, A.O. Konig, A.J. Lowe, S.F. Madsen, G. Matyas, R.C. Munro, F. Popescu, D. Slade, H. Tabbener, S.G.M. de Vries, B. Ziegenhagen, J.L. de Beaulieu and A. Kremer 2002. Identification of refugia and post-glacial colonisation routes of European white oaks based on chloroplast DNA and fossil pollen evidence. Forest Ecology And Management 156(1-3):49-74.

Petit, R.J., U.M. Csaikl, S. Bordacs, K. Burg, E. Coart, J. Cottrell, B. van Dam, J.F. Deans, S. Dumolin-Lapegue, S. Fineschi, R. Finkeldey, A. Gillies, I. Glaz, P.G. Goicoechea, J.S. Jensen, A.O. Konig, A.J. Lowe, S.F. Madsen, G. Matyas, R.C. Munro, M. Olalde, M.H. Pemonge, F. Popescu, D. Slade, H. Tabbener, D. Taurchini, S.G.M.de Vries, B. Ziegenhagen and A. Kremer 2002. Chloroplast DNA variation in European white oaks - phylogeography and patterns of diversity based on data from over 2600 populations. Forest Ecology And Management 156(1-3):5-26.

Petit, R.J., A. Kremer and D.B. Wagner 1993. Geographic structure of chloroplast DNA polymorphisms in European oaks. Theoretical And Applied Genetics 87(1-2):122-128.

Rule, M. 1983. The Mary Rose: The Excavation and Raising of Henry VIII's Flagship. London: Conway Maritime Press.

Squirrell, J.P. and R.W. Clarke 1987. An investigation into the condition and conservation of the hull of the Mary Rose. Part I: assessment of the hull timbers. Studies in Conservation 32(4):153-162.

Tani, N., Y. Tsumura and H. Sato 2003. Nuclear gene sequences and DNA variation of Cryptomeria japonica samples from the postglacial period. Molecular Ecology 12(4):859-868.

The Mary Rose Trust 2002. The Mary Rose - Museum and ship hall. Portsmouth: The Mary Rose Trust.

Yanisch-Perron, C., J. Vieira and J. Messing 1985. Improved m13 phage cloning vectors and host strains - nucleotide-sequences of the m13mp18 and pUC19 vectors. Gene 33(1):103-119. 